\title{
Islamic Radicalism: Between Accusation and Reality
}

\author{
Muntasir \\ Universitas Malikussaleh Lhokseumawe Aceh, Indonesia \\ tgkdrsaiful@gmail.com
}

\begin{abstract}
This paper discusses about islamic radicalism is accusation or reality. The essence is that similar acts of radicalism are also carried out by people of other religions in the world. This signifies that radicalism is actually not an issue of Islam, but it is a matter of the human race, whatever religion is adopted. Apart from various views that unilaterally claim that radicalism is synonymous with Islam, the reality can be said that radicalism is also carried out by followers of other religions. The manifestation of acts of violence committed by the human ummah which do not exclude any legitimate religion that they adhere to is driven by despair towards various highly unwanted phenomena. Terror acts are the last alternative after various other choices have a dead end.
\end{abstract}

Keywords : Islamic; radicalism; accusation; reality

\section{Introduction}

The birth of hardline groups in various countries is the basic root of the existence of discourse and radical militant terms. The bombings that took place in several places and the biggest tragedy of this century in the form of the attacks on WTC USA on September 11, 2001 were among the lists of violence carried out by various groups called radicals. The radicalism movement that occurs in any of these places has been carried out by various groups of followers of any faith and religion. But in reality the one who has always been accused of various acts of violence is the Islamic community.

Only a few minutes after the tragedy of the WTC bombing, the leaders of the country immediately accused Islamic radical groups of being the perpetrators. Even though many scientists doubted it. Some of them even consider it a conspiracy created by Bush himself and the nation of Israel (Peter Knight 2004). ${ }^{1}$ Likewise with the tragedy of the bombings in London in 2005, British officials immediately accused the perpetrators of being in contact with Islamic groups. In fact, three Muslims were forced to be freed from accusations that they were involved in the bombing.

The excitement of America and the western world in campaigning for the issue of terrorist Islam, in general and globally has resulted in excessive suspicion and the emergence of discriminatory government actions and policies against the identity of Islam in several countries. For example, such as the case of banning headscarves and veils / burkha which are considered to be somewhat identical to Islamic teachings. This is the beginning of the birth of Islamophobia in various countries in the world that is very discrediting and detrimental to the Islamic ummah. ${ }^{2}$

The essence is that similar acts of radicalism are also carried out by people of other religions in the world. This signifies that radicalism is actually not an issue of Islam, but it is a matter of the human race, whatever religion is adopted. We still remember the sarin gas tragedy which was sown by the Aum Shinrikyo group of Buddhists or Shintos in Tokyo in

\footnotetext{
${ }^{1}$ Peter Knight, 2004, Outrageus Conspiracy Theories : Popular and Official Responses to 9/11 In Germany and United States. Diunduh. http://ngc.dukejournals.org/cgi/reprint/35/1_103/165

2 Tiga Muslim Inggris Bebas dalam Kasus Bom London.. http://www.eramuslim.com/berita/dunia/tiga-musliminggris-bebas-dalam-kasus-bom-london.htm 
March 1995, which killed 12 people and injured more than 5,000 people (Kyle B. Olson 2000). ${ }^{3}$ Recently the world was also shocked by the actions of Nigerian Christian extremists who attacked a number of Muslim villages. As a result, around 67 Nigerian Muslims were killed. ${ }^{4}$ In 1992 in New Delhi India, Hindus massacred and destroyed the mosques of the Muslims, until there were 1,800 of the most popular Muslims in the trajedi. In the same year in February thousands of Muslims were shot, raped and burned alive in the Gujarat region of India, ${ }^{5}$ the region where Mahatma Gandhi was born. From Judaism there are always radical groups like the Zealots. Also, various ultra orthodox groups believe that God only chose the Jewish people and would win the holy war with every group that fought Israel. ${ }^{6}$ The ferocity carried out by the Israelites on behalf of the Palestinian people so that now it displays a perfect form of how the issue of radicalism is only an accusation and a trick to corner Islam.

The question now is in the dynamics of violence perpetrated by interfaith humanity like that, why Islam has always been accused in every movement of violence and terrorism that occurred. Why is radicalism always identified with Islam. This short article will provide a brief overview of the questions above by exploring the history and concepts of radicalism in relation to its link in the Islamic tradition.

\section{Review of Literature}

\subsection{Definition and History of the Birth of Discourse on Radicalism and Fundamentalism}

According to James Barr that the word fundamentalism originated from the title of the essay entitled "Fundamentals" which appeared in America around 1910-1915. This term is used to categorize exclusive theology, namely the absolute belief in revelation, the divinity of the Messiah, the miracle of Mary who gave birth when she was a virgin and other beliefs that are still believed by Christian fundamentalists until now. This term is used for evangelicals in the Protestant group as well as the Karzemy group which has grown rapidly as a sect in Christianity. Many also consider that fundamentalism is a group of rural communities, or a group of remote people who live in small towns that are mostly Protestant Christians (James Barr 1977). ${ }^{7}$

Then the fundamentalist movement became a religious militant movement that used political power, as a tool to combat what was considered a movement of liberalism, which threatened the stability of the state, family and the Church. According to Kaplan this kind of idealism of understanding fundamentalism began to blossom in the Russfelt period (Lionel Caplan 1987). ${ }^{8}$ While Garaudy had another opinion, that the use of fundamentalism did not yet exist in the large Roper dictionary until 1966. Only later in the small dictionary La Rose in 1966 had defined it very generously, namely the attitude of those who refused the conditional shield of faith according to new situations and conditions.

\footnotetext{
${ }^{3}$ Kyle B. Olson, 2000, Aum Shinrikyo: Once and Future Threat?, CDC Journal Vol.5 No.4 (July - August). http://www.cdc.gov/ncidod/eid/vol5no4/olson.htm

${ }^{4}$ Fundamentalis Kristen Nigeria Bantai 67 Muslim. http://swaramuslim.net/comments.php?id=1825_0_1_0_C

${ }^{5}$ Derita Muslim Minoritas di India, 2008, http://www.indoforum.org/archive/index.php/t-63851.html

${ }^{6}$ Akal Busuk : Fundamentalisme Agama; Pencorengan nama Tuhan, http://defrin.blogspot.com/search?q=fundamentalisme+Agama,

${ }^{7}$ James Barr, 1977, Fundamentalism, London : SCM Press, pp. 1-3.

${ }^{8}$ Lionel Caplan (ed),1987, Studies In Fundamentalism,London : Mac Millan Press, p. 1

DOI : https://doi.org/10.33258/birci.v2i2.256 
Based on the above facts, fundamentalism may be understood as a notion that makes religion a political ideology. This ideology makes religion the basis of its ideology which is used as the center of its government with the highest authority on religious leaders. All government activities and laws are also taken from the scriptures. And the basis of the state itself uses religious ideology. Whereas radicalism has several similar meanings, namely first, radical ideology or flow in politics. Second, ideology or sect that wants a change or renewal of social and politics in a hard or appropriate way and the third, extreme attitude in a stream. ${ }^{9}$ From this historical analysis, we may find the common thread of the term fundamentalism in the Christian tradition with its various streams. Although some people are reluctant to call themselves fundamentalists, like a group of people in the UK prefer to be mentioned by the name of the guards of the gospel.

According to Horace M. Kallen, radicalism is characterized by three general tendencies. First, radicalism is a response to ongoing conditions. The response appears in the form of evaluation, rejection, or even resistance. Issues that are rejected can be in the form of assumptions, ideas, institutions, or values that can be responsible for the sustainability of the situation that is rejected. Second, radicalism does not stop at rejection efforts, but continues to try to replace other arrangements. This characteristic shows that in radicalism a program or world view is contained. Radicals try hard to make the order instead of the existing order. And third, radicalists have a strong belief in the truth of the program or ideology they carry. In social movements, radicalists fight for beliefs that they think are right with emotional attitudes that lead to violence (Bahtiar Effendy and Hendro Prasetyo 1998). ${ }^{10}$

\section{Discussion}

\subsection{Stigma of Fundamentalism and Radicalism in Islam}

Harakah Islam which is known as the Islamic renewal and purification movement (Islamic reformism) the groups in Islamic society who carry out actions that lead to political movements. On this basis it must be seen by Westerners as a movement similar to what happened in the history of Christian civilization. And for this movement then western political leaders, scientists and media gave rise to the term Islamic fundamentalism. Richard Nixon (former president of the USA in 1969 - 1974) mentions that there are five characteristics of Islamic fundamentalism. First, those who acted rather to restore Islamic civilization. Secondly, those who are committed to maintaining their belief in implementing Islamic law. The third, those who hold that Islam is religion and the state, the fourth is that it has a strong anti-western outlook. And fifth, those who make the history of Islamic glory as petuntuk and lessons of the future (Muhammad Nurrodin Usman 2003). ${ }^{11}$

Feeling on these characteristics they then try to map out who is the legal or any group that enters this fundamental Islam. For most westerners, seeing that Ibn Taymiyyah was the main inspiration of this Islamic renewal movement which was later dubbed the West as the father of fundamentalism in Islam in modern times. The name of fundamentalist Islam was then increasingly popular with the increasing number of emerging Islamic movements engaged in the socio-political field. Among them are the Muslim Brotherhood, the Islamic

\footnotetext{
${ }^{9}$ Departemen Pendidikan dan Kebudayaan, 1990, Kamus Besar Bahasa Indonesia, Jakarta : Balai Pustaka, p. 719.

${ }^{10}$ Quoted from: Bahtiar Effendy dan Hendro Prasetyo, 1998, Radikalisme Agama, Jakarta : PPIM - IAIN

${ }^{11}$ Muhammad Nurrodin Usman, 2003, Menanti Detik-detik Kematian Barat, Solo : Era Intermedia, p. 31

DOI : https://doi.org/10.33258/birci.v2i2.256 
Jama'at in Pakistan and other Islamic organizations or movements that are considered in line and in line with them such as Front Islamique du Salut (FIS) in Algeria, Front Islam Nasional (NIF) in Sudan, Hamas and the Jihad Movement Islam in Palestine, Milisi Hizbullah in Lebanon and others (Endang Turmudi 2005). ${ }^{12}$

As in Christian history, this Islamic purification movement also transformed itself into a political movement. Movements like the one above, then became an organization that opposed western political ideology by using the principles of Islamic ideology which originated from the Al-Qur'an and the Hadith of the Prophet. The imposition of ideology carried out by the West, for example, by using the colonization of colonialism and hegemony, requires that Islam must fight to totally change the hegemony. Such resistance was feared by the West and later claimed that it was a radical or fundamental act.

Western fears of the Islamic prominence have increasingly occurred after the collapse of the ideology of communism. The western world views Islam as the only movement of world civilization that is a threat to them. There is no more feared political turmoil beyond the rise of the Islamic movement. The strengthening of Muslim solidarity towards its oppressed brothers and sisters is a phenomenon that is used by the western media to campaign for the label of Islamic radicalism. Western accusations and propaganda over Islam as a religion that sustains the radicalism movement has become an international rhetoric for labeling Islam with various slanted designations, such as Islamic fundamentalism, radical Islam, terrorist Islam and others.

According to Nuim Hidayat, the stigmatization of Islam as well as western media is also carried out by many of their intellectuals, so that they are able to shape public opinion. As proof of his statement, the Nuim quoted Francis Fukuyama's statement stating that the common enemy of mankind is radical Islam (Nuim Hidayat 2009). ${ }^{13}$ The same statement was also conveyed by Herzog (the sixth Israeli president in the 1980s) that the disease of Fundamental Islam is spreading rapidly and is a danger not only to Jewish society, but also to humanity in general (Adian Husaini 2005). ${ }^{14}$

In line with the facts above, the statement conveyed by Lampton, as quoted by Camplan, said that in Islam there is a central core of fundamentalism. While in Christian or Jewish teachings even though it has the potential for the emergence of fundamentalist movements but not fundamentalism perfectly. In addition to eliminating the seeds of fundamentalism, Lampton suggests that the sentences contained in the Islamic holy book, even though the coming of God still requires translation, explanation, judgment which is humanly present (Lionel Caplan 1987). ${ }^{15}$ Generally, the reason for the re-translation of religious texts recommended by the West is for Islam to respond and adapt to the demands of changing times and humanity. A reason that departs from the origin of the western mind itself which is based on their logical philosophy and is far from the substance of the teachings of Islam itself. This has been described by Allah in the Koran that if the truth follows their own will, heaven and earth will be destroyed along with everything in it. ${ }^{16}$

As a comparison and to influence the mind of the Islamic community itself by the West creates a new term to show Islamic groups otherwise. Terms such as pluralist Islam, Inslam

\footnotetext{
${ }^{12}$ Endang Turmudi et.al, 2005, Islam and Radicalism in Indonesia, Jakarta: LIPI Press, p. 55

${ }^{13}$ Nuim Hidayat, 2009, Imperialisme Baru, Jakarta : Gema Insani Press, p. 196

${ }^{14}$ Adian Husaini, 2005, Wajah Peradaban Barat, Jakarta : Gema Insani Press, p : 183

${ }^{15}$ Lionel Caplan, ibid, $\mathrm{p}: 33$

${ }^{16}$ Al-Quran Al-Mukminun Verse: 70-71

DOI : https://doi.org/10.33258/birci.v2i2.256 
Liberal, Islamic anti-violence, Inclusive Islam, tolerant Islam and so on are intended by the West to make dichotomies with other Islamic groups. In addition, propaganda was intended to dampen the Islamic movement against any policies and actions carried out by the West that harm Islam. If there are few actions taken by Islamic groups, the West will loudly say to other Islamic communities that is what groups mean not inclusive and intolerant.

\subsection{Islam is not a Radical Religion}

The perfection and universality of Islam is the main substance of Islamic teachings. AlQur'an as a source of Islamic teachings has guaranteed this perfection that will always be cherished by Allah of all time. ${ }^{17}$ In addition, the universality of its teachings makes the religion brought by the apostle Muhammad SAW a mercy religion for all nature. ${ }^{18}$ That is the basic principle which is the core of education taught and practiced in Islam. In being taught how to be able to live side by side with other religious people. This is reflected in the flexible attitude of Islamic teachings in carrying out peace and humanism in any form of religion adopted. And it clarifies that Islam is a religion that can live side by side with other nonMuslims, as the Prophet demonstrated in the establishment of the Madinah for the first time. With the bai'ah (declaration) carried out by the Apostle clearly showed a tolerant attitude to live peacefully alongside the Christians and Jews at that time.

Universality of Islamic teachings does not then limit the fulfillment of Islamic rights as a religion. As a religion and one of the ideologies that develops in the world, Islam chooses identity and dignity that must be maintained. It is the duty of their adherents to maintain the purity and truth that they have believed. The war that was carried out by the Messenger of Allah with his companions several tens of times the essence was to defend this truth. Although naturally there is no humanity who wants the war to happen. As said by Allah SWT that he was obliged to fight even though he was unpleasant. Because sometimes something is not liked but actually it is good, when on the contrary something is liked but when it is not good for us. ${ }^{19}$

In the theory of political science according to Nuim Hidayat that war must be prepared so that the community can be peaceful (Nuim Hidayat 2009) ${ }^{20}$ The war preparations intended here are in the form of preparation of strength (syaukah) to maintain the survival of themselves not being disturbed by other groups. Typically violence and injustice over one group occur because there is no balance between one another. The single dominant structure with super power that is owned by the USA today, for example, has made it a country of violence that has invaded the sovereignty of other countries such as Iraq (Endang Turmudi 2005). ${ }^{21}$ This kind of thing will not be if there is a balance between the various groups that exist.

To prepare for syaukah it is then in Islam that it requires jihad to its people. The concept of jihad which is accused of being the basis of violence in Islam is essentially a part of Islamic efforts to balance to fight against tyranny committed against Islam. Therefore jihad taught in Islam is principally jihad in an effort to defend itself from the attacks and tyranny of others on Islam. This is in accordance with the word of God that fight in the way of Allah

\footnotetext{
${ }^{17}$ Al-Quran Surat Al-Maidah Verse : 3

${ }^{18}$ Al-Quran Surat Al-Anbiya Verse : 107

${ }^{19}$ Al-Quran Surat Al-BAqarah Verse : 216.

${ }^{20}$ Nuim Hidayat, ibid, p : 118

${ }^{21}$ Endang Turmudi,ibid, $\mathrm{p}: 46$ 
those who fight you, but do not transgress. Lo! Allah does not like those who transgress. ${ }^{22}$ From the word of God it shows that jihad in Islam is an effort to achieve a goal that is blessed by Allah. Jihad is permitted to protect the identity, murmur and honor of Islam and the Muslims.

\section{Conclusion}

Apart from various views that unilaterally claim that radicalism is synonymous with Islam, the reality can be said that radicalism is also carried out by followers of other religions. The manifestation of acts of violence committed by the human ummah which do not exclude any legitimate religion that they adhere to is driven by despair towards various highly unwanted phenomena. Terror acts are the last alternative after various other choices have a dead end.

After the collapse of the ideology of communism in the Western world, Islam was seen as number one enemy that was partitioned by various policies. The policy resistance efforts carried out are always claimed by acts of terrorism. It is not only that every action and policy taken by the state or society of Islam which is suspected by the West is considered as an endowment or seed of malignancy. These accusations later became their rhetoric for fighting and interfering in a deeper Islamic society.

\section{References}

Al-Quran Al-Qarim

Adian Husaini, 2005, Wajah Peradaban Barat, Jakarta : Gema Insani Press

Akal Busuk: Fundamentalisme Agama; Pencorengan nama Tuhan, http://defrin.blogspot.com/search?q=fundamentalisme+Agama

Bahtiar Effendy dan Hendro Prasetyo, 1998, Radikalisme Agama, Jakarta : PPIM - IAIN

Endang Turmudi et.al, 2005, Islam dan Radikalisme di Indonesia, Jakarta : LIPI Press

Departemen Pendidikan dan Kebudayaan, 1990, Kamus Besar Bahasa Indonesia, Jakarta : Balai Pustaka

Derita Muslim Minoritas di India, 2008, http://www.indoforum.org/archive/index.php/t63851.html

Fundamentalis Kristen Nigeria Bantai 67 Muslim. http://swaramuslim.net/comments.php?id=1825_0_1_0_C

James Barr, 1977, Fundamentalism, London : SCM Press

Kyle B. Olson, 2000, Aum Shinrikyo: Once and Future Threat?, CDC Journal Vol.5 No.4 (July - August). http://www.cdc.gov/ncidod/eid/vol5no4/olson.htm

Lionel Caplan (ed), 1987, Studies In Fundamentalism, London : Mac Millan Press

Muhammad Nurrodin Usman, 2003, Menanti Detik-detik Kematian Barat, Solo : Era Intermedia

Nuim Hidayat, 2009, Imperialisme Baru, Jakarta : Gema Insani Press

Peter Knight, tt, Outrageus Conspiracy Theories : Popular and Official Responses to 9/11 In Germany and United States. Diunduh. http://ngc.dukejournals.org/cgi/reprint/35/1_103/165

Tiga Muslim Inggris Bebas dalam Kasus Bom London.. http://www.eramuslim.com/berita/dunia/tigamuslim-inggris-bebas-dalam-kasus-bom-london.htm

${ }^{22}$ Al-Quran Suarat Al-Baqarah verse : 190

DOI : https://doi.org/10.33258/birci.v2i2.256 